Article

\title{
Purification and characterization of alkaline chitinase from Paenibacillus pasadenensis CS0611
}

\author{
Xiaoxiao Guo a, Pei Xua a, Minhua Zong b, Wenyong Lou a,b,* \\ a Laboratory of Applied Biocatalysis, School of Food Science and Engineering, South China University of Technology, Guangzhou 510640, Guangdong, \\ China \\ b State Key Laboratory of Pulp and Paper Engineering, South China University of Technology, Guangzhou 510640, Guangdong, China
}

\section{A R T I C L E I N F}

\section{Article history:}

Received 28 November 2016

Accepted 14 January 2017

Published 5 April 2017

\section{Keywords:}

Chitinase

Purification

Characterization

Paenibacillus pasadenensis CS0611

\begin{abstract}
A B S T R A C T
An extracellular chitinase produced by Paenibacillus pasadenensis CS0611 was purified by ammonium sulfate precipitation, HiTrap DEAE FF and HiLoad 26/600 Superdex 200pg column chromatography. The apparent molecular mass determined by sodium dodecyl sulfate polyacrylamide gel electrophoresis was $69 \mathrm{kDa}$. The optimum $\mathrm{pH}$ and optimum temperature of the chitinase were 5.0 and $50{ }^{\circ} \mathrm{C}$, respectively. The enzyme showed high stability at alkaline $\mathrm{pH}$ values and temperatures below $40^{\circ} \mathrm{C}$. Additionally, the metal ions $\mathrm{Mn}^{2+}, \mathrm{Mg}^{2+}$, and $\mathrm{Co}^{2+}$ inhibited activity of the chitinase. The chitinase was active on colloidal chitin with an apparent $K_{\mathrm{m}}$ of $4.41 \mathrm{mg} / \mathrm{mL}$ and $V_{\max }$ of $1.08 \mathrm{mg} / \mathrm{min}$. Substrate spectrum analysis indicated that the chitinase reacted preferentially with the glucosidic bond between GlcNAc-GlcNAc. The enzymatic hydrolysate was analyzed by high-performance liquid chromatography and thin layer chromatography, and clearly showed that a subunit of (GlcNAc) 2 was the main hydrolysis product.
\end{abstract}

(C) 2017, Dalian Institute of Chemical Physics, Chinese Academy of Sciences. Published by Elsevier B.V. All rights reserved.

\section{Introduction}

Biomass resources waste can cause environmental issues because of its persistence and accumulation. The best response to this problem is to utilize waste for the production of valuable products. Chitin, a homopolymer formed by covalent $\beta-1,4$ linkages of $N$-acetyl-D-glucosamine [1], is widely distributed as a structural component in arthropod exoskeletons, connective tissues, and fungal cell walls [2]. It is the second most abundant polysaccharide found in nature after cellulose [3]. Thousands of metric tons of biowaste are being generated globally every year [4]. An important source of chitin is the shells of shrimps and crabs [5]. To date, chitin has not been applied to large-scale industrial use because of its extreme insolubility [6]. The conversion of chitin-containing wastes to oligosaccharides has attracted increasing attention because these oligosaccharides have useful biological activities, such as antifungal, antitumor, and immunity enhancement activities $[7,8]$.

Traditionally, concentrated acids or alkalis are used in the chitin-hydrolysis reaction in industry, and there are many issues with this process, including production of undesired products such as large quantities of short chain oligosaccharides, a high cost for separation, and serious environmental pollution [9-12]. Consequently, research has focused on the development of enzymatic degradation methods under mild conditions and reduction of pollution [13]. The chitin-hydrolyzing enzyme has been found in a board range of organisms including numerous bacteria, fungi, insects, animals, and vascular plants [14]. Chitinase plays an important role in catalyzing the hydrolysis of glycosidic bonds in polysaccharides

\footnotetext{
* Corresponding author. Tel/Fax: +86-20-22236669; E-mail: wylou@scut.edu.cn

This work was supported by the National Natural Science Foundation of China $(21336002,21376096,21676104)$.

DOI: 10.1016/S1872-2067(17)62787-6| http://www.sciencedirect.com/science/journal/18722067 | Chin. J. Catal., Vol. 38, No. 4, April 2017
} 
into low molecular mass chitin oligosaccharide [15]. Based on the homology of amino acid sequences and catalytic mechanism, these chitinases are classified as either glycoside hydrolase family 18 or 19 [16].

To obtain enzymes that are capable of hydrolyzing chitinous waste and producing specific oligosaccharides, we screened chitin-degrading bacteria from soil for chitinase activity in a culture medium. The aim of this work was to purify and characterize chitinase from Paenibacillus pasadenensis CS0611. Furthermore, this chitinase was applied to production of (GlcNAc) 2 using colloidal chitin and crab shell powder (CSP) as substrates.

\section{Materials and methods}

\subsection{Materials}

Crab shell was purchased from Nantong Xingcheng Biological Products Factory (Nantong, China). To prepare CSP, the waste was dried, milled, and sieved to particles less than 100-mesh. Colloidal chitin was prepared according to an established method [17]. Chitin powder (5 g) (Sigma-Aldrich, St. Louis, MO) was added slowly to $100 \mathrm{~mL}$ of concentrated $\mathrm{HCl}$ with vigorous stirring on ice overnight. Then, the mixture was added dropwise to $1 \mathrm{~L}$ of ice-cold ethanol with rapid stirring for $4 \mathrm{~h}$. Finally, the precipitate was collected by suction filtration and washed with water until the washing solution was neutral. The colloidal chitin was stored at $4{ }^{\circ} \mathrm{C}$ for subsequent use. Diacetylchitobiose and $\mathrm{N}$-acetylglucosamine were purchased from Bozhihuili Co. (Qingdao, China) and Sigma-Aldrich, respectively. All other reagents used were of analytic grade.

\subsection{Microorganism preparation}

P. pasadenensis CS0611 was previously isolated from soils around chitin biological products factories in Shandong China, using crab shell powder as the only carbon source, and stored at China Center for Type Culture Collection (CCTCC M2014458). It was identified based on morphological characterization and 16s rDNA sequence analysis. The strain was incubated in $50 \mathrm{~mL}$ of liquid medium in a $250-\mathrm{mL}$ flask $(10 \mathrm{~g} / \mathrm{L}$ crab shell powder, $0.7 \mathrm{~g} / \mathrm{L} \mathrm{K}_{2} \mathrm{HPO}_{4}, 0.3 \mathrm{~g} / \mathrm{L} \mathrm{KH}_{2} \mathrm{PO}_{4}, 0.5 \mathrm{~g} / \mathrm{L}$ $\mathrm{MgSO}_{4}, 1 \mathrm{~g} / \mathrm{L}$ peptone) at $37^{\circ} \mathrm{C}$ for $48 \mathrm{~h}$ and $180 \mathrm{rpm}$.

\subsection{Chitinase activity assay}

The chitinase activity was determined by measuring the release of reducing sugar using colloidal chitin as a substrate. The reaction mixture contained $0.5 \mathrm{~mL}$ of enzyme solution and 1 $\mathrm{mL}$ of colloidal chitin (3\% colloidal chitin in $100 \mathrm{mmol} / \mathrm{L}, \mathrm{pH}$ 5.0 citrate buffer) and was incubated at $50{ }^{\circ} \mathrm{C}$ for $30 \mathrm{~min}$ with a magnetic stirrer. Then, the reaction was terminated by placing the flask in a boiling water bath for 5 min. After centrifugation (13500 g, $5 \mathrm{~min}$ ), the chitinase activity of the supernatant was determined according to an established method with $\mathrm{N}$-acetylglucosamine as a standard [18]. One unit of chitinase activity was defined as the amount of the enzyme that cata- lyzed the release of $1 \mu \mathrm{mol}$ of $\mathrm{N}$-acetylglucosamine per minute. The protein concentration was determined using the Branford method with bovine serum albumin as the standard [19].

\subsection{Preparation of chitinase}

The resulting 800-mL culture was centrifuged $(6010 \mathrm{~g}, 10$ min) at $4{ }^{\circ} \mathrm{C}$ to obtain cell-free supernatant. Ammonium sulfate was added to the supernatant to $80 \%$ saturation. Subsequently, the protein deposit was collected by centrifugation at $13500 \mathrm{~g}$ for $20 \mathrm{~min}$ and dialyzed overnight in $20 \mathrm{mmol} / \mathrm{L} \mathrm{Tris} / \mathrm{HCl}$ buffer ( $\mathrm{pH}$ 8.9). The enzyme solution was loaded on a HiTrap DEAE FF column (5 mL column volume, GE Healthcare, Fairfield. CT.USA) pre-equilibrated with Tris/HCl (20 mmol/L, pH 8.9), and eluted with $0-1 \mathrm{~mol} / \mathrm{L} \mathrm{NaCl}$ in the same buffer. The active fractions which showed chitinase activity were collected, concentrated with an ultra-filtration membrane (3 kDa, Millipore, Billerica, MA), and then applied to a HiLoad 26/600 Superdex 200pg column (310-330 mL column volume, GE Healthcare, Fairfield. CT. USA) pre-equilibrated with Tris/HCl $(20 \mathrm{mmol} / \mathrm{L}$, $\mathrm{pH}$ 8.9) containing $150 \mathrm{~mol} / \mathrm{L} \mathrm{NaCl}$. The protein fractions were analyzed for chitinase activity.

\subsection{Sodium dodecyl sulfate polyacrylamide gel electrophoresis and matrix-assisted laser desorption/ionization time-of-flight mass spectrometry}

The purified proteins were analyzed by sodium dodecyl sulfate polyacrylamide gel electrophoresis (SDS-PAGE) as described by Laemmli [20]. After electrophoresis, the gels were stained with Coomassie Brilliant Blue R-250 and decolorized in $10 \%$ acetic acid. The band of interest was removed from the gel and digested by trypsin. After freeze-drying, the sample was mixed with matrix solution. Mass spectra were recorded on a matrix-assisted laser desorption/ionization time-of-flight mass spectrometer (MALDI-TOF-MS, Bruker Daltonics, Karlsruhe. Germany), which was equipped with a nitrogen laser operated at $337 \mathrm{~nm}$ in linear mode[21]. The fragment spectra were compared with the NCBI protein database using BLAST.

\subsection{Effects of $p H$, temperature, metal ions, and reagents on enzyme activity}

To study the effect of $\mathrm{pH}$ on chitinase activity, enzyme activity was investigated in different reaction buffers with $\mathrm{pH}$ values ranging from 3.0 to 12.0 . The buffer systems $(100 \mathrm{mmol} / \mathrm{L})$ used were citric acid ( $\mathrm{pH}$ 3.0-6.0), sodium phosphate buffer $(\mathrm{pH}$ 6.0-8.0), and glycine sodium hydroxide buffer $(\mathrm{pH}$ 8.0-10.0), sodium bicarbonate-sodium hydroxide buffer $\mathrm{pH}$ 10.0-11.0), and potassium chloride-sodium hydroxide buffer (pH 11.0-12.0). pH stability was tested by pre-incubating purified enzyme in these buffers at $30^{\circ} \mathrm{C}$ for $3 \mathrm{~h}$, and then measuring the enzyme activity under standard assay conditions.

The optimum temperature for chitinase was determined in $100 \mathrm{mmol} / \mathrm{L}$ citric acid (pH 5.0) using a temperature range of $20-80{ }^{\circ} \mathrm{C}$. Thermal stability was determined by incubating the enzyme at the selected temperature for different periods, and 
then measuring the residual activity under standard assay conditions.

The effects of metal ions on enzyme activity were determined after addition of $\mathrm{Fe}^{2+}, \mathrm{Fe}^{3+}, \mathrm{Mg}^{2+}, \mathrm{Ba}^{2+}, \mathrm{Zn}^{2+}, \mathrm{Ca}^{2+}, \mathrm{K}^{+}$, $\mathrm{Mn}^{2+}, \mathrm{Cd}^{2+}$, and $\mathrm{Cu}^{2+}$ at different concentrations. The effects of the reagents Triton X-100, Tween-80, ethylene diamine tetraacetic acid (EDTA), sodium dodecyl sulfate, urea, $\beta$-mercaptoethanol were also evaluated. The enzyme activity obtained without addition of any metal ion or chemical reagent was set as $100 \%$ for comparison purposes.

\subsection{Substrate specificity and enzyme kinetics}

Purified chitinase was reacted with powdered shrimp crab shells, powdered chitin, colloidal chitin, powdered chitosan, cellulose, soluble starch, and carboxymethyl cellulose in citric acid buffer (100 mmol/L, pH 5.0), each at a concentration of 30 $\mathrm{mg} / \mathrm{mL}$ under standard conditions. The degree of substrate hydrolysis was determined by the 3,5-dinitrosalicylic acid method. Colloidal chitin with a final concentration ranging from 5 to $100 \mathrm{mg} / \mathrm{mL}$ was used for determination of $K_{\mathrm{m}}$ and $V_{\text {max. }}$ Assays performed were performed under optimal conditions and terminated after 5 min. The kinetic constants $K_{\mathrm{m}}$ and $V_{\text {max }}$ were obtained from Hanes-Woolf plots.

\subsection{Chitin Hydrolysis}

The chitin hydrolysates were tested by thin layer chromatography (TLC) and high-performance liquid chromatography (HPLC). For TLC, the samples were spotted on the silica gel plates, then the mobile phase of $n$-butanol: methanol: ammonia: $\mathrm{H}_{2} \mathrm{O}(5: 4: 2: 1, v / v)$ was applied. The results were revealed by spraying the plates with aniline diphenylamine chromogenic agent $1 \mathrm{~g}$ of diphenylamine dissolved in a mixture of $1 \mathrm{~mL}$ of phenylamine, $5 \mathrm{~mL}$ of $85 \%$ phosphoric acid, $0.5 \mathrm{~mL}$ of concentrated $\mathrm{HCl}$, and $50 \mathrm{~mL}$ of acetone) and heated for a few minutes at $100{ }^{\circ} \mathrm{C}$. In addition, the sample was analyzed using an HPLC system equipped with a DIEX P680 HPLC pump, a Alltech ELSD2000ES detector, and a $\mathrm{NH}_{2} \mathrm{P}-50(4 \mathrm{E})$ column $(250 \mathrm{~mm} \times$ $4.6 \mathrm{~mm}$ i.d., partical size $5 \mathrm{um}$, Shodex, Tokyo. Japan). The mobile phase was acetonitrile and water $(7: 3, v / v)$ with a flow rate of $0.6 \mathrm{~mL} / \mathrm{min}$. The column temperature was $30^{\circ} \mathrm{C}$.

\section{Results and discussion}

\subsection{Purification of chitinase}

Extracellular chitinase from P. pasadenensis CS0611 was pu-

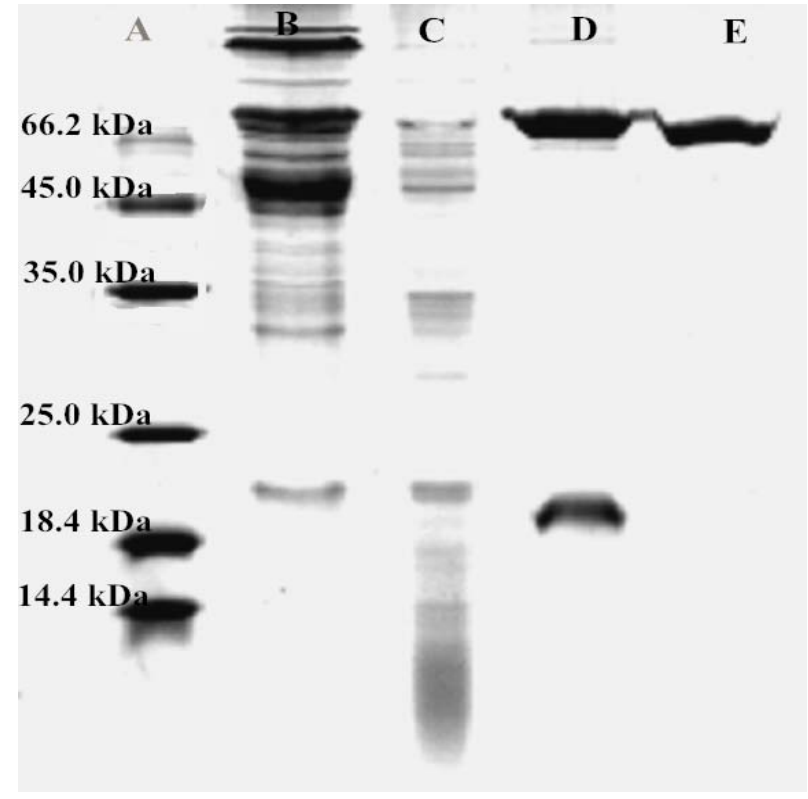

Fig. 1. SDS-PAGE analysis of chitinase: Lane A, protein standard molecular weight marker; Lane B, crude enzyme; Lane C, ammonium sulfate precipitation, Lane D: HiTrap DEAE FF; and Lane E, Hiload 26/600 Superdex 200pg.

rified for analysis. The crude enzyme obtained was purified using ammonium sulfate, and HiTrap DEAE FF column and Hiload 26/200 superdex 200pg columns (Table 1). The purification factor of the final product was 5.30, the specific activity was $10.28 \mathrm{U} / \mathrm{mg}$, and the yield was $15.7 \%$. Wang et al. [22] purified chitinase from Bacillus subtilis W-118 by ammonium sulfate fractionation, and DEAE-Sepharose CL-6B and Sephacryl S-200 gel filtration, and obtained a purification factor of 6.97 and chitinase specific activity of $7.1 \mathrm{U} / \mathrm{mg}$. For P. pasadenensis NCIM-5434, chitinase was obtained in a $24.96 \%$ with a purification factor of 8.87 [23].

\subsection{Identification of purified chitinase}

SDS-PAGE analysis of the purified enzyme was performed to verify its purity (Fig. 1). The apparent molecular mass of the chitinase was $69 \mathrm{kDa}$. In earlier reports, the molecular mass of chitinase from other species varied from 20 to $80 \mathrm{kDa}$ (Table 2). MALDI-TOF-MS was used to identify proteins showing chitinase activity appearing at $69 \mathrm{kDa}$ on SDS-PAGE. This is a simple method for preliminarily identification of proteins with unknown sequences. The mass spectrum of the $69 \mathrm{kDa}$ protein was identical to the chitinase from P. pasadenensis (GenBank accession number gi655151624) (Table 3).

Table 1

Purification of $P$. pasadenensis CS0611 chitinase.

\begin{tabular}{lccccc}
\hline Purification step & Total protein $(\mathrm{mg})$ & Total activity (U) & Specific activity (U/mg) & Yield (\%) & Purification factor \\
\hline Crude enzyme & 121.96 & 236.5 & 1.94 & 100.0 & 1.00 \\
Ammonium sulfate & 79.59 & 158.0 & 1.99 & 66.8 & 1.02 \\
HiTrap DEAE FF & 10.27 & 61.2 & 5.96 & 58.9 & 3.07 \\
Hiload 26/600 Superdex 200pg & 3.61 & 37.1 & 10.28 & 15.7 & 5.30 \\
\hline
\end{tabular}


Table 2

Properties of chitinase from this study compared with chitinase from other Paenibacillus species.

\begin{tabular}{|c|c|c|c|c|c|c|}
\hline \multirow{2}{*}{ Strain name } & \multirow{2}{*}{$\begin{array}{c}\text { Mol.wt } \\
\text { (kDa) }\end{array}$} & \multicolumn{2}{|c|}{ Optimum } & \multicolumn{2}{|c|}{ Stability } & \multirow{2}{*}{ Reference } \\
\hline & & $\mathrm{pH}$ & Temp $\left({ }^{\circ} \mathrm{C}\right)$ & $\mathrm{pH}$ & Temp $\left({ }^{\circ} \mathrm{C}\right)$ & \\
\hline P. sp. D1 & 56.6 & 5.0 & 50 & - & - & Singh et al. [24] \\
\hline P. thermoaerophilus TC22-2b & 48.0 & 4.0 & 60 & $4.0-10.0$ & $\sim 40$ & Ueda et al. [25] \\
\hline P. barengoltzii & 67.9 & 3.5 & 60 & $3.0-9.0$ & $\sim 55$ & Fu et al. [26] \\
\hline P. pasadenensis NCIM 5434 & 35.0 & 10.0 & 37 & - & - & Loni et al. [23] \\
\hline P. illinoisensis KJA-424 & 54.0 & 5.6 & 60 & - & - & Jung et al. [27] \\
\hline P. pasadenensis CS0611 & 69.0 & 5.0 & 50 & $4.0-10.0$ & $\sim 35$ & This work \\
\hline
\end{tabular}

Table 3

Identification of chitinase by MALDI-TOF-MS.

\begin{tabular}{lccc}
\hline Protein & Peptide sequence & Identified protein & Score \\
\hline & K.LVLGMAFYGR.G & & \\
Chitinase & R.EVFANSSVDFIR.K & Chitinase from & \\
& K.IVGYYASWAAYGR.A & 393 & gi655151624 \\
& K.GLAGAMFWETSGDRNK.T & Paenibacillus pasadenenss & \\
\hline
\end{tabular}

\subsection{Biochemical characterization of chitinase}

\subsubsection{Effect of $p H$ and temperature}

Temperature and $\mathrm{pH}$ play important roles in enzyme activity and stability. The effects of $\mathrm{pH}$ on the activity and stability of chitinase are shown in Fig. 2. The chitinase exhibited maximum activity at pH 5.0. From pH 5.0 to 7.0, the activity was higher than those at other $\mathrm{pH}$ values, indicating that the enzyme was active in a neutral environment. With regard to $\mathrm{pH}$ stability, the enzyme was stable over a broad pH range from 4.0 to 11.0. The residual enzyme activity was nearly $90 \%$, even at $\mathrm{pH} 11.0$. The excellent stability in alkaline environments indicated that denaturation of the chitinase because of $\mathrm{pH}$ in this work was, to some degree, reversible over a certain $\mathrm{pH}$ range. However, at $\mathrm{pH} 12.0$, the chitinase activity was almost non-existent. It is likely that amino acid residues near the catalytic or binding center of the enzyme are responsible for such uniqueness. The chitinase in this work was more suitable in alkaline media than the chitinase from Bacillus amyloliquefaciens V656 [13]. Most of the purified bacterial chitinase showed high activity and stability within the $\mathrm{pH}$ range of 4.0-10.0 [28]. The enzyme from Streptomyces sp. CS495 was active from pH 8.0 to 13.6 with the highest activity at $\mathrm{pH} 12.5$ [29]. For practical application, two methods can be used to maintain high activity at alkaline $\mathrm{pH}$. The first is immobilization of chitinase, which could stabilize the structure to some extent and allow for application even under harsh $\mathrm{pH}$ or temperature conditions. The second is molecular modification of chitinase at the gene level using molecular biology technology.

The optimum temperature for the chitinase was $50{ }^{\circ} \mathrm{C}$ (Fig. 3(a)). At temperatures above $50{ }^{\circ} \mathrm{C}$, the enzyme activity decreased quickly and largely. The activity dropped to less than half of the highest activity, which was obtained at $70{ }^{\circ} \mathrm{C}$. The chitinase had relatively high thermostability at temperatures below $40{ }^{\circ} \mathrm{C}$ (Fig. 3(b)), even after incubation for $24 \mathrm{~h}$. Howev- er, the residual enzyme activity reduced to $45 \%$ at $40{ }^{\circ} \mathrm{C}$ after incubation for more than $4 \mathrm{~h}$. Generally, the optimal temperature range for chitinase from microorganisms is $40-50{ }^{\circ} \mathrm{C}$
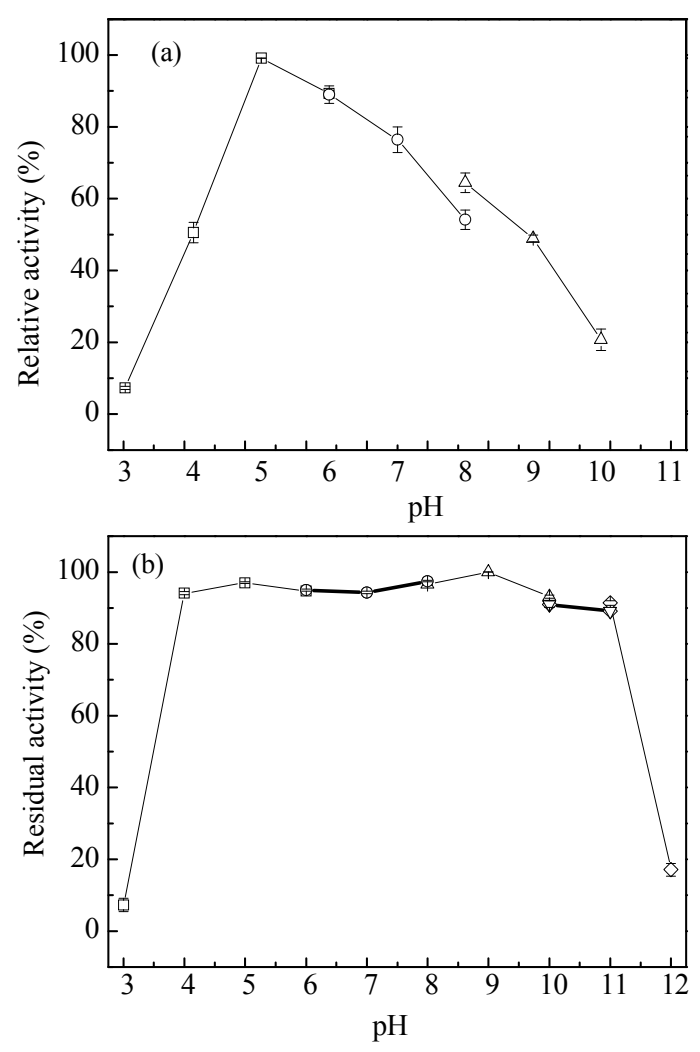

Fig. 2. (a) Effect of pH on chitinase activity. (b) pH stability of chitinase with citric acid ( $\mathrm{pH} 3.0-6.0$, open square), sodium phosphate buffer $\mathrm{pH}$ 6.0-8.0, open circle), glycine-sodium hydroxide buffer ( $\mathrm{pH} 8.0-10.0$, upright triangle), sodium bicarbonate-sodium hydroxide buffer $(\mathrm{pH}$ 10.0-11.0, inverted triangle),potassium chloride-sodium hydroxide buffer (pH 11.0-12.0, open diamond). 

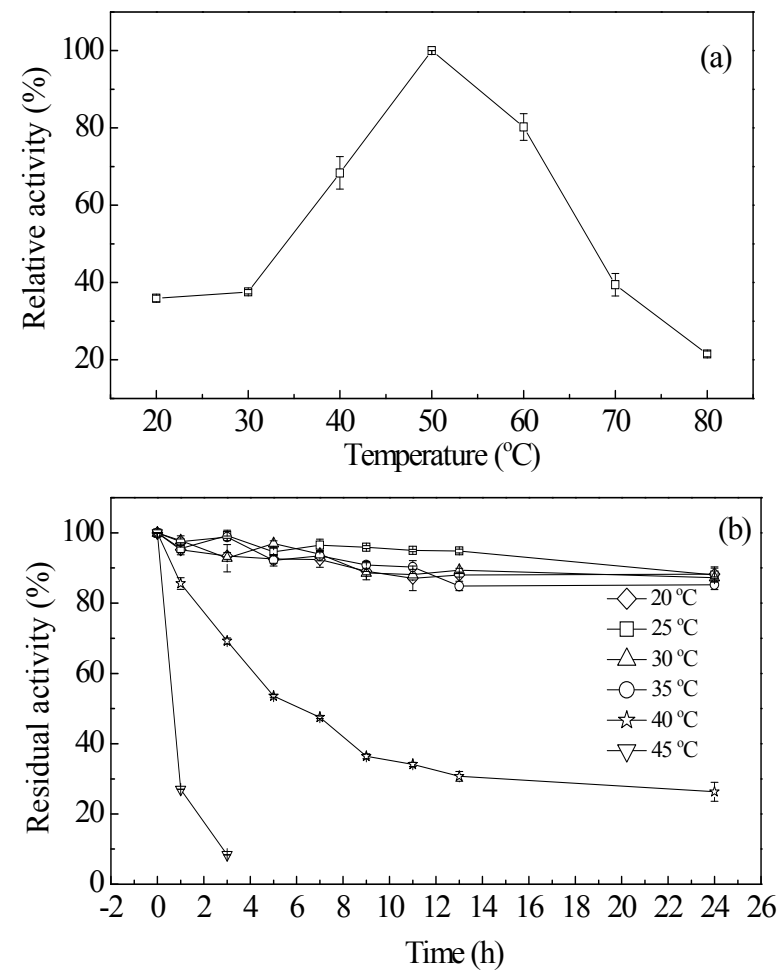

Fig. 3. (a) Effect of temperature on chitinase; (b) Temperature stability of chitinase.

$[24,30,31]$. The properties of chitinase from other species are shown in Table 2. The optimum temperature for chitinase from P. pasadenensis NCIM5434 is $37^{\circ} \mathrm{C}[23]$. The optimal temperature for the chitinase in the present study was similar to that from Streptomyces sp. [32]. A high reaction temperature is more suitable for industrial application than a low temperature. The optimum temperature of an enzyme is the result of the mutual effects of denaturation and activity increases with temperature increasing. Considering the relative poor thermostability of the chitinase at $50^{\circ} \mathrm{C}$, further technology like immobilization or directed mutation could be used to improve the thermostability to meet the requirements for practical application.

\subsubsection{Effects of metal ions and chemical reagents}

Metal ions play important roles in biological catalysis [33]. In the present study, we investigated the influence of metal ions on chitinase activity (Table 4). None of the metal ions tested provided good activation of the chitinase. This result was similar to that for chitinase from Streptomyces violaceusniger [34]. Three ions, $\mathrm{Mn}^{2+}, \mathrm{Mg}^{2+}$ and $\mathrm{Co}^{2+}$, could inhibit chitinase activity at different levels. The chitinase activity was affected by urea, Tween 80, and Triton X-100 to a low degree (Table 5). EDTA, a chelating agent capable of binding metal ions in solution, showed no obvious inhibition of the chitinase activity, suggesting that the chitinase was not a metal-enzyme. As opposed to the chitinase from Paenicibacillus barengoltzii [26], the major inhibitor of enzyme activity was SDS, since it could break the inter- and intra-molecular hydrogen bonds, unfold protein, and
Table 4

Effects of metal ions on the chitinase activity of P. pasadenensis CS0611.

\begin{tabular}{lcc}
\hline \multirow{2}{*}{ Metal ions } & \multicolumn{2}{c}{ Relative activity ${ }^{a}$ (\%) } \\
\cline { 2 - 3 } Control & $1 \mathrm{mmol} / \mathrm{L}$ & $5 \mathrm{mmol} / \mathrm{L}$ \\
$\mathrm{K}^{+}$ & $102.2 \pm 2.0$ & 100.0 \\
$\mathrm{Cd}^{2+}$ & $101.9 \pm 2.2$ & $96.2 \pm 2.6$ \\
$\mathrm{Zn}^{2+}$ & $98.3 \pm 0.7$ & $94.7 \pm 3.8$ \\
$\mathrm{Fe}^{2+}$ & $98.3 \pm 2.5$ & $94.9 \pm 3.7$ \\
$\mathrm{Fe}^{3+}$ & $100.5 \pm 2.4$ & $91.4 \pm 3.4$ \\
$\mathrm{Cu}^{2+}$ & $101.6 \pm 2.6$ & $91.7 \pm 0.8$ \\
$\mathrm{Mn}^{2+}$ & $66.1 \pm 0.9$ & $94.5 \pm 3.3$ \\
$\mathrm{Mg}^{2+}$ & $97.1 \pm 2.0$ & $51.2 \pm 0.2$ \\
$\mathrm{Ba}^{2+}$ & $97.6 \pm 1.6$ & $79.1 \pm 2.7$ \\
$\mathrm{Co}^{2+}$ & $99.8 \pm 0.8$ & $92.1 \pm 2.5$ \\
\hline
\end{tabular}

${ }^{a}$ Activities were assayed under the standard condition. The reaction mixture was consisted of colloidal chitin in $100 \mathrm{mmol} / \mathrm{L}$ citrate buffer (pH 5.0) and enzyme solution which stood with tested substances at 4 ${ }^{\circ} \mathrm{C}$ for $3 \mathrm{~h}$. Each of data was assayed in triplicate and the average with standard deviations was measured.

Table 5

Effect of chemical agents on chitinase activity.

\begin{tabular}{lcc}
\hline Chemical agents & Concentration & Relative activity (\%) \\
\hline Control & 0 & 100.0 \\
SDS & $5 \mathrm{mmol} / \mathrm{L}$ & $15.1 \pm 0.68$ \\
EDTA & $5 \mathrm{mmol} / \mathrm{L}$ & $90.1 \pm 0.95$ \\
Tween 80 & $1 \%(v / v)$ & $105.0 \pm 3.5$ \\
Triton X-100 & $1 \%(v / v)$ & $94.5 \pm 3.9$ \\
U & $5 \mathrm{mmol} / \mathrm{L}$ & $99.8 \pm 0.56$ \\
$\beta$-Mercaptoethanol & $1 \%(v / v)$ & $81.9 \pm 1.8$ \\
\hline
\end{tabular}

destroy the secondary and tertiary protein structure.

\subsubsection{Substrate specificity and kinetic parameters}

The substrate specificity of the chitinase was assayed using different chitin substrates. The chitinase from P. pasadenensis CS0611 had the best digestive ability for colloidal chitin, exhibiting a activity of $100 \%$. Relatively low activity was observed in the presence of chitin powder and crab shell powder, and it did not show activity towards chitosan, carboxymethyl cellulose, and cellulose. Similar results were found for chitinase from Bacillus sp. [35]. In addition, the chitinase exhibited relatively low activity (11.4\% and 6.38\%) towards chitosan with different degrees of deacetylation (80\% and $90 \%$, respectively). There was no hydrolysis activity when the degree of deacetylation was 95\%. Therefore, the chitin from this study has high specificity for hydrolyzing glycosidic bonds between GlcNAc-GlcNAc.

To investigate the ability of chitinase to degrade chitin oligosaccharides and its affinity characteristics on the substrate, the kinetic constants of purified chitinase were calculated by fitting the data to a Hanes-Woolf plot. The $K_{\mathrm{m}}$ and $V_{\max }$ were $4.41 \mathrm{mg} / \mathrm{mL}$ and $1.08 \mathrm{mg} / \mathrm{min}$, respectively. The $K_{\mathrm{m}}$ was lower than that of the chitinase from Bacilus sp. BG-11 [36]. The $K_{\mathrm{m}}$ of chitinase from Streptomyces sp. was determined using a Lineweaver-Burk plot to be $6.74 \mathrm{mg} / \mathrm{mL}$ [30]. Results suggested 
that there was higher affinity of the purified chitinase towards the substrate compared with the above two chitinases.

\subsection{Chitin hydrolysate}

The hydrolytic products of colloidal chitin and crab shell powder by chitinase were analyzed by both TLC and HPLC. The TLC results (Fig. 4) indicated that (GlcNAc) 2 was the principal oligosaccharide produced by the hydrolytic action of different substrates. Most bacterial chitinase reported so far, such as chitinase from Vibrio parahaemolyticus [37], produce diacetylchitobiose as a major product from colloidal chitin. Based on the hydrolysate formed, the chitinase from Chitinibacter sp. GC72 was characterized as an exohydrolytic $\mathrm{N}$-acetylglucosaminidase, which has the ability to hydrolyze colloidal chitin into GlcNAc as the main product [38]. B. licheniformis ChiA could efficiently covert colloidal chitin to GlcNAc and (GlcNAc) 2 as major products, and (GlcNAc) 3 as a minor product [39]. Meanwhile, HPLC analysis (Fig. 5) also showed that the hydrolysis product at a retention time of 13.5 was mainly (GlcNAc)2 under the same reaction conditions. (Glc$\mathrm{NAc})_{2}$ has been widely used for the synthesis of biologically active compounds as a starting material [40].

\section{Conclusions}

Chitinase was purified from a newly isolated P. pasadenensis CS0611 strain. The enzyme was stable and active in alkaline environments. Above $40{ }^{\circ} \mathrm{C}$, the enzyme lost activity rapidly. None of tested metal ions had an active effect on purified chitinase. The enzyme was inhibited by $\mathrm{Mn}^{2+}, \mathrm{Mg}^{2+}, \mathrm{Co}^{2+}$ to some extent. Substrate specificity suggested that the chitinase has high specificity for hydrolyzing the glycosidic bond between

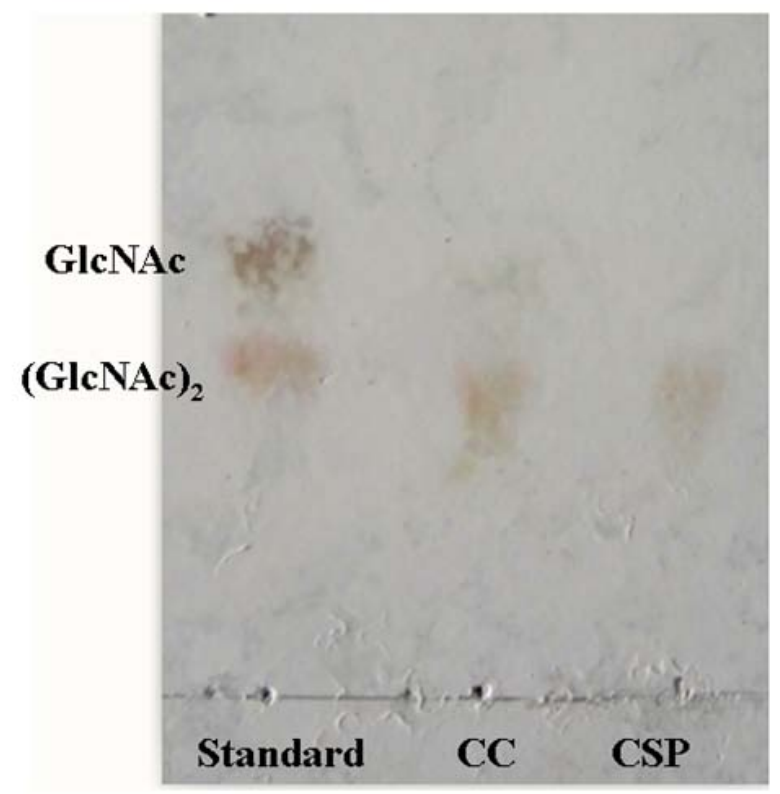

Fig. 4. TLC analysis of hydrolytic products. Plot shows the chitin hydrolysate with colloidal chitin (CC) and crab shell powder (CSP) at $50{ }^{\circ} \mathrm{C}$ and pH 5.0 with chitinase from P. pasadenensis CS0611 for $30 \mathrm{~min}$.
(1)

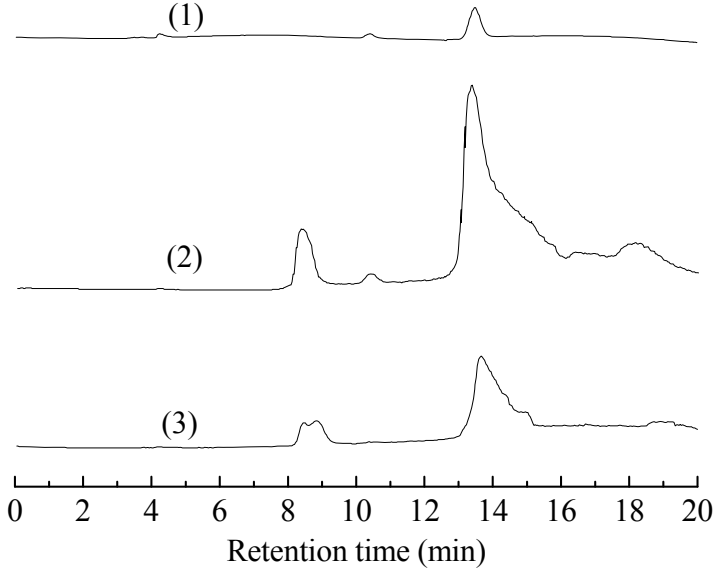

Fig. 5. HPLC chromatogram analysis (1) (GlcNAc) 2 standard, (2) colloidal chitin hydrolysate, (3) crab shell powder hydrolysate.

GlcNAc-GlcNAc. Analysis of the hydrolysates of different substrates showed that the chitinase produced (GlcNAc) 2 as the mainly hydrolyzed product. Thus, the chitinase shows great potential in the production of (GlcNAc) 2 with crab shell waste.

\section{References}

[1] H. S. Kim, K. N. Timmis, P. N. Golyshin. Appl. Microbiol. Biotechnol., 2007, 75, 1275-1283.

[2] Y. G. Lee, K. C. Chung, S. G. Wi, J. C. Lee, H. J. Bae, Protein Express. Purif., 2009, 65, 244-250.

[3] B. García-Fraga, A. F. da Silva, J. López-Seijas, C. Sieiro, Biochem. Eng. J., 2015, 93, 84-93.

[4] V. L. Pachapur, K. Guemiza, T. Rouissi, S. J. Sarma, S. K. Brar, J. Chem. Technol. Biotechnol, 2016, 91, 2331-2339.

[5] J. K. Chen, C. R. Shen, C. L. Liu, Marine Drugs, 2010, 8, 2493-2516.

[6] N. Jeraj, B. Kunic, H. Lenasi, K. Breskvar, Enzyme Microbial. Technol., 2006, 39, 1294-1299.

[7] D. H. Dai, W. L. Hu, G. R. Huang, W. Li, Afr. J. Biotechnol., 2011, 10, 2476-2485.

[8] K. V. H. Prashanth, R. N. Tharanathan, Biochim. Biophys. Acta-Gen. Sub., 2005, 1722, 22-29.

[9] V. Gohel, A. Singh, M. Vimal, P. Ashwini, H. S. Chhatpar, Afr. J. Biotechnol., 2006, 5, 54-72.

[10] H. Sashiwa, S. Fujishima, N. Yamano, N. Kawasaki, A. Nakayama, E. Muraki, M. Sukwattanasinitt, R. Pichyangkura, S. Aiba, Carbohyd. Polym., 2003, 51, 391-395.

[11] B. Bhushan, J. Appl. Microbiol., 2000, 88, 800-808.

[12] K. Okazaki, Y. Yamashita, M. Noda, N. Sueyoshi, I. Kameshita, S. Hayakawa, Biosci. Biotechnol. Biochem., 2004, 68, 341-351.

[13] S. L. Wang, S. J. Chen, C. L. Wang, Carbohyd. Res., 2008, 343, 1171-1179.

[14] F. Khoushab, M. Yamabhai, Marine Drugs, 2010, 8, 1988-2012.

[15] R. Hamid, M. A. Khan, M. Ahmad, M. M. Ahmad, M. Z. Abdin, J. Musarrat, S. Javed, J. Pharm. Bioal. Sci., 2013, 5, 21-29.

[16] W. Ubhayasekera, Polym. Int., 2011, 60, 890-896.

[17] R. Chandrasekaran, K. Revathi, S. Nisha, S. A. Kirubakaran, S. Sathish-Narayanan, S. Senthil-Nathan, Pesticide Biochem. Phys., 2012, 104, 65-71.

[18] T. Imoto, K. Yagishita, Agri. Biol. Chem., 2014, 35, 1154-1156.

[19] M. M. Bradford, Anal. Biochem., 1976, 72, 248-254. 


\title{
Graphical Abstract
}

Chin. J. Catal., 2017, 38: 665-672 doi: 10.1016/S1872-2067(17)62787-6

\section{Purification and characterization of alkaline chitinase from Paenibacillus pasadenensis CS0611}

Xiaoxiao Guo, Pei Xu, Minhua Zong, Wenyong Lou*

South China University of Technology

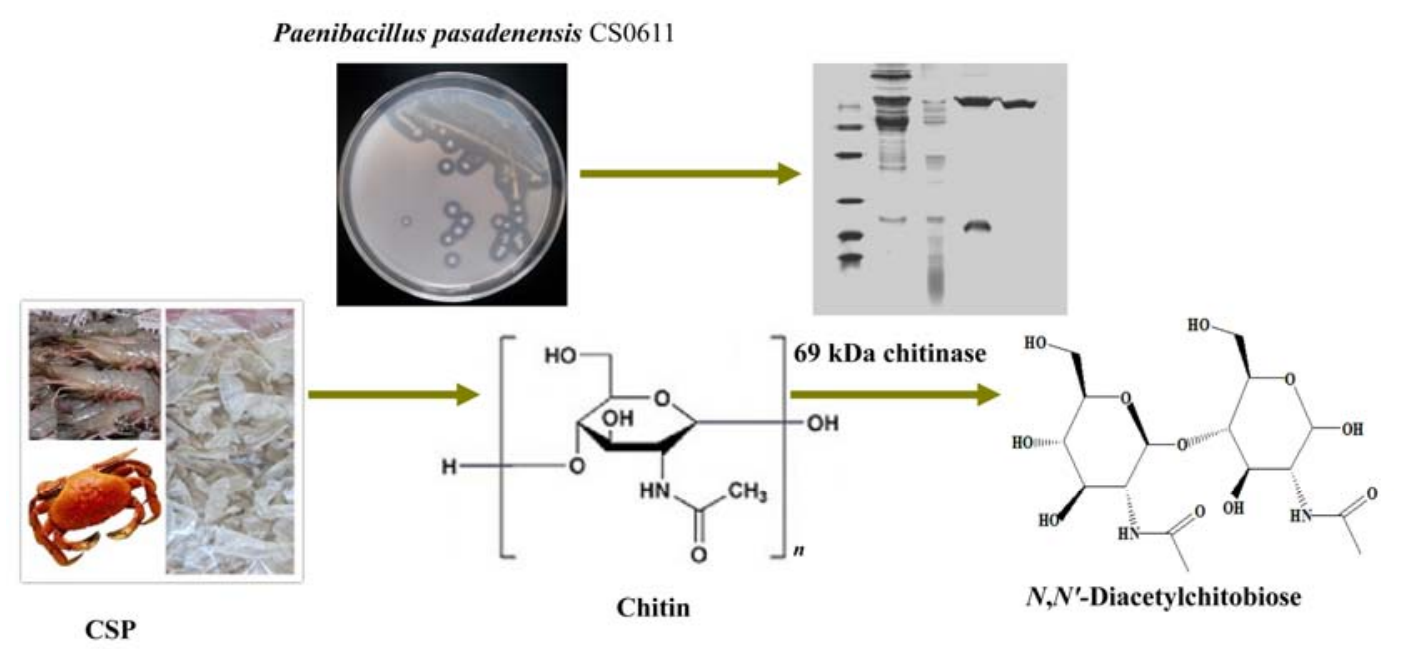

A highly efficient chitinase from Paenibacillus pasadenensis CS0611 was purified and characterized for the first time. Furthermore, the main product (GlcNAc) ${ }_{2}$ was studied using different substrates.

[20] U. K. Laemmli, Nature, 1970, 227, 680-685.

[21] L. M. B. Rigueira, D. Lana, D. M. dos Santos, A. M. Pimenta, R. Augusti, L. M. Costa, Food Chem., 2016, 211, 910-915.

[22] S. L. Wang, T. Y. Lin, Y. H. Yen, H. F. Liao, Y. J. Chen, Carbohydr. Res., 2006, 341, 2507-2515.

[23] P. P. Loni, J. U. Patil, S. S. Phugare, S. S. Bajekal, J. Basic Microbiol., 2014, 54, 1080-1089.

[24] A. K. Singh, H. S. Chhatpar, Appl. Biochem. Biotechnol, 2011, 164, 77-88.

[25] J. Ueda, N. Kurosawa, World J. Microbiol. Biotechnol., 2015, 31, 135-143.

[26] X. Fu, Q. Yan, J. Wang, S. Yang, Z. Jiang, Int. J. Biol. Macromol., 2016, 91, 973-979.

[27] W. J. Jung, J. H. Kuk, K. Y. Kim, T. H. Kim, R. D. Park, J. Microbiol. Biotechnol, 2005, 15, 274-280.

[28] S. L. Wang, I. L. Shih, T. W. Liang, C. H. Wang, J. Agric. Food Chem., 2002, 50, 2241-2248.

[29] S. Meena, R. K. Gothwal, M. K. Mohan, P. Ghosh, Extremophiles, 2014, 18, 451-462.

[30] N. Karthik, P. Binod, A. Pandey, Bioresour. Technol., 2015, 188,
195-201.

[31] P. Mander, S. S. Cho, Y. H. Choi, S. Panthi, Y. S. Choi, H. M. Kim, J. C. Yoo, Archi. Pharm. Res., 2016, 39, 878-886.

[32] G. C. Pradeep, Y. H. Choi, Y. S. Choi, S. E. Suh, J. H. Seong, S. S. Cho, M. S. Bae, J. C. Yoo, Process Biochem., 2014, 49, 223-229.

[33] Y. Han, B. J. Yang, F. L. Zhang, X. L. Miao, Z. Y. Li, Marine Biotechnol., 2009, 11, 132-140.

[34] C. Andreini, I. Bertini, G. Cavallaro, G. L. Holliday, J. M. Thornton, J. Biol. Inorg. Chem., 2008, 13, 1205-1218.

[35] A. Nagpure, R. K. Gupta, J. Basic Microbiol., 2013, 53, 429-439.

[36] B. Bhushan, G. S. Hoondal, Biotechnol. Lett., 1998, 20, 157-159.

[37] K. Kadokura, A. Rokutani, M. Yamamoto, T. Ikegami, H. Sugita, S. Itoi, W. Hakamata, T.Nishio T. Oku, Appl. Microbiol. Biotechnol, 2007, 75, 357-365.

[38] C. Gao, A. Zhang, K. Q. Chen, Z. K. Hao, J. M. Tong, P. K. Ouyang, Biochem. Eng. J., 2015, 97, 59-64.

[39] C. Songsiriritthigul, S. Lapboonrueng, P. Pechsrichuang, P. Pesatcha, M. Yamabhai, Bioresour. Technol, 2010, 101, 4096-4103.

[40] S. Kobayashi, T. Kiyosada, S. Shoda, Tetrahedron Lett., 1997, 38, 2111-2112.

\section{来源于类芽孢杆菌属碱性甲壳素酶的分离纯化及其性质}

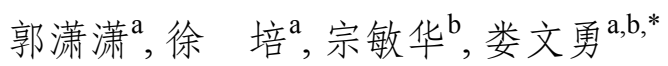 \\ a华南理工大学食品科学与工程学院, 广东广州510640 \\ 华南理工大学制浆造纸工程国家重点实验室, 广东广州510640
}

摘要: 甲壳素, 又名几丁质(chitin), 是自然界中含量仅次于纤维素的第二大天然多糖, 有第六生命要素之美称. 其主要存在 于甲壳类动物的外壳、真菌细胞的细胞壁以及一些昆虫的外壳中, 每年自然界中约有 100 多亿吨甲壳素生成. 甲壳素是由 2-乙酰氨基-2-脱氧-D-吡喃葡萄糖和2-氨基-2-脱氧-D-吡喃葡萄糖通过 $\beta-1,4$ 糖苷键连接而成的二元线性聚合物, 分子链中 
分布许多羟基、氨基及乙酰氨基, 形成大量分子间及分子内氢键, 致使其结晶度较高, 化学性质十分稳定, 直接利用较为困 难. 甲壳素不溶于稀酸、稀碱以及一般有机溶剂, 工业上常用强酸强碱法处理甲壳素, 以制备壳寡糖类产品, 但该方法具有 产品结构不单一, 环境污染较为严重等缺点. 甲壳素酶可特异性水解甲壳素链中 $\beta-1,4$ 糖苷键, 得到甲壳寡糖和 $N$-乙酰氨基 葡萄糖. 酶解法降解甲壳素工艺简单、反应条件温和、环境友好, 有很好的应用前景.

我们以Paenibacillus pasadenensis CS0611为出发菌株, 以蟹壳粉末为培养基唯一碳源及氮源, 在适宜条件下培养 $48 \mathrm{~h}$. 发酵液经离心、硫酸铵 $(80 \%$ 饱和度)盐析、透析除盐后得到粗酶液. 再利用HiTrap DEAE FF离子交换层析和HiLoad 26/600 Superdex $200 \mathrm{pg}$ 凝胶过滤层析对该粗酶液进行分离纯化, 以得到电泳纯甲壳素酶. 所制备甲壳素酶比活力为 $10.28 \mathrm{U} / \mathrm{mg}$, 最终纯化倍数为 5.3 , 酶活得率为 $15.7 \%$. SDS-PAGE 结果表明, 该甲壳素酶相对分子质量约为 $69 \mathrm{kDa}$. 后经 MALDI-TOF-MS鉴定, 该酶部分肽段和来源于另一株Paenibacillus pasadenenss的甲壳素酶(accession No: gi655151624)具 有较高的同源性, 进一步证实所纯化蛋白为甲壳素酶.

对上述纯化的甲壳素酶的酶学性质进行研究, 结果发现: 其最适反应温度为 $50{ }^{\circ} \mathrm{C}$, 在 $20-35^{\circ} \mathrm{C}$ 内有较好的稳定性, $50{ }^{\circ} \mathrm{C}$ 及以上热稳定性较差; 最适 $\mathrm{pH}$ 为 5.0 , 在 $\mathrm{pH} 4.0-11.0$ 间具有较高稳定性, 表明该酶具有很好的耐碱性; 金属离子对该酶 催化活性没有明显的激活作用, 表明该甲壳素酶是非金属酶. 同时, 对该酶的底物特异性进行研究, 发现该酶对胶体甲壳 素和甲壳素水解能力较强, 对淀粉和纤维素无水解能力, 对不同脱乙酰度的壳聚糖的水解程度随脱乙酰度不同而变化, 表 明该酶只能特异性识别并降解GlcNAc-GlcNAc之间的糖苷键; 以胶体甲壳素为底物时, 米氏常数 $K_{\mathrm{m}}$ 为 $4.41 \mathrm{mg} / \mathrm{mL}$, 最大反 应初速度为 $1.08 \mathrm{mg} / \mathrm{min}$. 利用薄板层析和高效液相色谱对酶解产物进行分析, 结果表明该甲壳素酶对胶体甲壳素的降解 产物主要是 $(\mathrm{GlcNAc})_{2}$. 综上所述, 本研究所涉甲壳素酶在甲壳二糖的酶法制备方面具有较好的应用前景.

关键词: 甲壳素酶; 分离纯化; 酶学性质; 类芽狍杆菌属

收稿日期: 2016-11-28. 接受日期: 2017-01-14. 出版日期: 2017-04-05.

*通讯联系人. 电话/传真: (020)22236669; 电子信箱: wylou@scut.edu.cn

基金来源：国家自然科学基金(21336002;21376096;21676104).

本文的英文电子版由Elsevier出版社在ScienceDirect上出版(http://www.sciencedirect.com/science/journal/18722067). 